\title{
Derivative financial instruments in the activity of enterprises of the agrarian sphere of economy
}

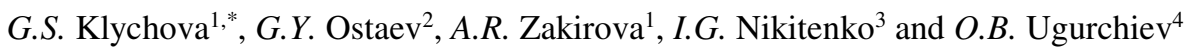 \\ ${ }^{1}$ Kazan State Agrarian University, Kazan, 420015, Russia \\ ${ }^{2}$ Izhevsk State Agricultural Academy, Izhevsk, 426069, Russia \\ ${ }^{3}$ Kazan (Volga region) Federal University, Kazan, 420008, Russia \\ ${ }^{4}$ Ingush State University, Magas, 386001, Russia
}

\begin{abstract}
The article presents the ways of strengthening the financial state, solvency, investment attractiveness and financial stability of agricultural organizations by expanding existing and finding new markets for products, additional sources of funding, wide use of derivative financial instruments and hedging in the practice of management. The subject of the research is the consideration of modern ways of bringing agricultural products from the producer to the end consumer. The purpose of the study is to reflect the possibilities of using derivative financial instruments in settlements of agricultural organizations with counterparties. In the course of the study, the concept of derivative financial instruments, which are widely used in the world stock exchange practice, but at present in Russia have not yet found wide application, is given. The economic efficiency of agricultural organizations is largely determined by the organization of sales of agricultural products, the choice of distribution channels in order to reduce the delivery time of products to consumers, improve its quality and reduce the cost of its implementation. It is concluded that in the current economic situation successful sales of agricultural products can be held through the exchange market through forward (futures) contracts for the immediate transfer of rights and obligations to perform the real delivery of agricultural products in the future on a certain date.
\end{abstract}

\section{Introduction}

Often, agricultural organizations in Russia are faced with the urgent problem of ensuring financial stability to reduce the possibility of bankruptcy. The importance of studying and solving this problem increases significantly due to the instability of the world economy, including Russia, caused by sanctions pressure from Western countries, the decline in trade turnover with Asian countries, etc.

Many agricultural organizations cannot increase the volume of production, reduce the number of employees, as the lack of financial resources, low prices for agricultural products in conditions of rising inflation does not allow one to conduct agricultural activities profitably. The solution to these problems is directly related to strengthening the financial condition and increasing the financial sustainability of agricultural organizations [1]. It is achieved by finding markets for products, independence from sources of funding, willingness and ability of the organization to function and develop, maintaining the balance of assets and liabilities in the changing internal and external environment of the organization, creating conditions for its solvency and investment attractiveness with an acceptable level of risk [2].
Financial stability of the agricultural organization will be possible only when fixed assets, intangible assets, current assets will be financed by own funds; unreasonable accounts receivable and accounts payable will not be allowed; settlements on liabilities of the enterprise will be made on time [3].

The main task of agricultural producers is to find sufficient sources of funding for all agricultural works. Despite the lack of money, agricultural producers do not stop investing in the replenishment of machine-tractors and vehicle fleet, the purchase of seeds. Both the price of grain and the cost of agricultural machinery do not leave the producer with financial "reserves" for the future [4, 5]. We have to look for a way out.

Modern conditions of market economy force agricultural producers to conduct a continuous search for effective sales channels of agricultural products [6].

The development of market relations will lead to the sale of more and more commodity agricultural products through market structures. Commodity exchanges will take a significant place: here agricultural organizations will be able to conduct transactions for the sale of agricultural products and simultaneously conclude contracts using derivative financial instruments for the purchase of necessary means of production [7].

Currently, a large number of studies in the field of derivative financial instruments (derivatives), but a

\footnotetext{
* Corresponding author: kgaukgs@ mail.ru
} 
holistic picture of their practical use is lacking [8, 9]. Therefore, in the study of methods of development of economic relations, it is important to use derivative financial instruments that take into account the behavior of financial market participants to achieve corporate goals and the choice of effective mechanisms for the formation and use of innovative financial instruments.

\section{Methods}

The following types of derivative financial products are distinguished, such as futures, futures contracts, swaps, options, differentiated contracts, etc. [10, 11].

Derivative securities are used to achieve the following purposes:

- in the insurance of financial risks (hedging) - an economic entity of the agricultural industry carries out planning of the upcoming harvest in order to protect the future harvest (products) from adverse price fluctuations in the market [12].

- Derivative (derivative) securities are tools for effective income generation.

But it is also worth remembering that operations with these financial instruments are the riskiest compared to other securities.

Derivative financial instruments are traded on the futures market, while the primary instruments are traded on the spot market [13]. The main differences between the futures market and the spot market are deferred settlement and the limited life of the contracts.

The main objectives of the futures market are:

- Increasing stability in the real economy, including agriculture, by insuring producers against price spikes (also said to be hedging).

- Speculative profits for traders on price fluctuations.

A futures contract is an agreement for the future delivery of a base commodity at the current price. The following types of transactions with derivative financial instruments are distinguished:

- transactions on mutual transfer of rights and obligations in relation to a real commodity, which is available and can be delivered immediately;

- transactions on mutual cession of rights and duties in relation to real commodity with future delivery in exact term (forward transactions);

- transactions on mutual transfer of rights and obligations in relation to standard contracts on delivery of the real exchange commodity (futures transactions);

- the cession of rights to the future transfer of rights and obligations regarding the real exchange commodity or the contract for the delivery of the exchange commodity (option deals) $[14,15]$.

Derivative financial instruments are characterized by the following properties: maturity, derivability and the ability to use the effect of financial leverage (Fig. 1).

Operations with the use of derivative financial instruments hedge financial risks that may adversely affect the financial results of the agricultural organization and its financial position [16]. In Russian practice, more often than not, credit institutions can initiate operations with derivative financial instruments (Table 1).

For a more illustrative example, let us present the grain market for forward contracts in Figure 2.

As can be seen from Figure 2, the volume of trading in the grain market for forward contracts fluctuated. It reached its highest value in 2018 and 2019 and amounted to 50 billion rubles, and in 2020 it decreased twofold to 25 billion rubles.

The conditions of a market economy required Russian agricultural producers to manage financial resources in an economically efficient way, which can independently initiate the process of forming a hedging mechanism and concluding transactions with derivative financial instruments $[17,18]$.

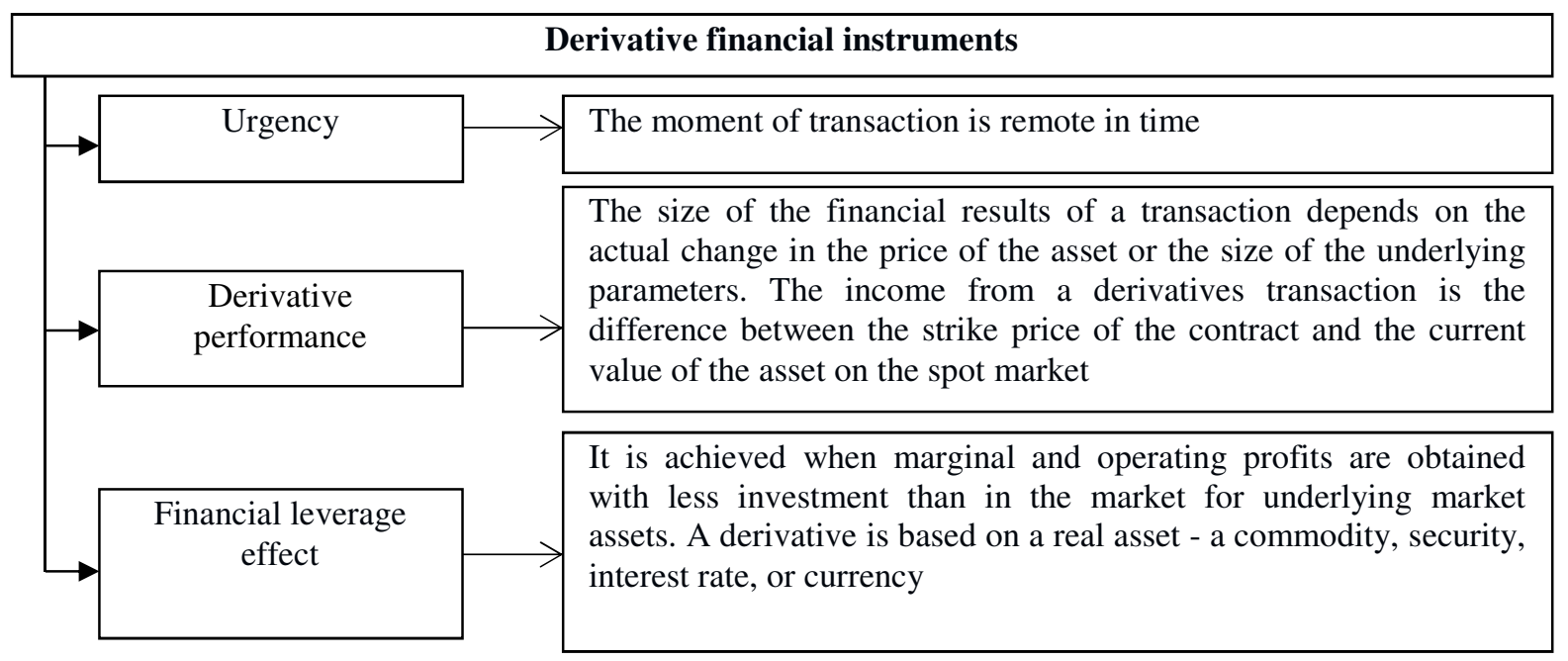

Fig. 1. Properties of derivative financial instruments. 
Table 1. Statistics of trading volumes on the Moscow Exchange, billion rubles.

\begin{tabular}{|c|c|c|c|c|c|c|c|}
\hline No. & Main indicators & 2015 & 2016 & 2017 & 2018 & 2019 & 2020 \\
\hline \multirow{3}{*}{1} & Stock market & 20557 & 23893 & 35413 & 40671 & 40662 & 54522 \\
\hline & $\begin{array}{l}\text { Market of shares, depositary } \\
\text { receipts and units }\end{array}$ & 9398 & 9277 & 9185 & 10830 & 12443 & 23905 \\
\hline & Bond market & 11159 & 14616 & 26228 & 29841 & 28219 & 30617 \\
\hline \multirow{3}{*}{2} & Money market & 213786 & 333883 & 377141 & 364216 & 346347 & 426781 \\
\hline & Repo operations & 180991 & 296226 & 339509 & 309913 & 292813 & 379135 \\
\hline & Credit market & 32795 & 37657 & 37631 & 54303 & 53534 & 47647 \\
\hline 3 & $\begin{array}{c}\text { Repo transactions with the } \\
\text { collateral management system } \\
\text { at national settlement } \\
\text { depository }\end{array}$ & 46361 & 47284 & 41922 & 17564 & 20105 & 6395 \\
\hline \multirow{3}{*}{4} & Foreign exchange market & 310837 & 329954 & 347671 & 348369 & 308274 & 328946 \\
\hline & Spot deals & 103335 & 107169 & 78380 & 86682 & 67370 & 96942 \\
\hline & Swap trades & 207502 & 222785 & 269291 & 261686 & 240904 & 232003 \\
\hline \multirow{5}{*}{5} & Derivatives market & 93713 & 115271 & 84497 & 89263 & 82370 & 129864 \\
\hline & Futures & 90231 & 109489 & 77624 & 82397 & 77376 & 124516 \\
\hline & $\begin{array}{c}\text { Futures share in the futures } \\
\text { market, } \%\end{array}$ & 96,28 & 94,98 & 91,87 & 92,31 & 93,94 & 95,9 \\
\hline & Options & 3482 & 5782 & 6873 & 6866 & 4994 & 5348 \\
\hline & $\begin{array}{c}\text { Options in the futures market, } \\
\%\end{array}$ & 3,72 & 5,02 & 8,13 & 7,69 & 6,06 & 4,1 \\
\hline 6 & $\begin{array}{c}\text { The market for standardized } \\
\text { derivative financial } \\
\text { instruments }\end{array}$ & 4 & 18 & 109 & 884 & 416 & 590 \\
\hline \multirow{4}{*}{7} & Commodity market & 117 & 137 & 128 & 152 & 86 & 78 \\
\hline & Precious metals market & 94 & 125 & 122 & 102 & 35 & 53 \\
\hline & Grain market & 22 & 12 & 6 & 50 & 50 & 25 \\
\hline & $\begin{array}{l}\text { Specific weight of the grain } \\
\text { market in the commodity } \\
\text { market, } \%\end{array}$ & 18,80 & 8,76 & 4,69 & 32,89 & 58,14 & 32,05 \\
\hline
\end{tabular}

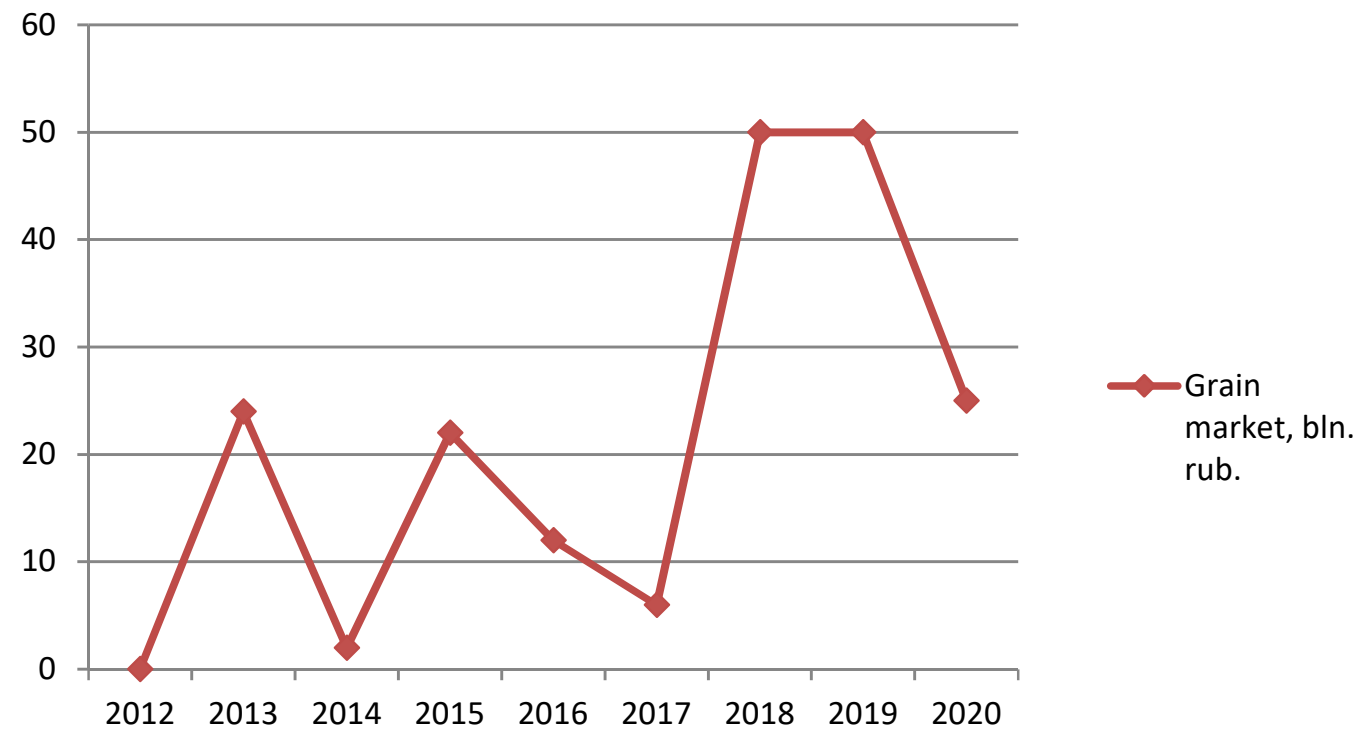

Fig. 2. Statistics of trading volumes of the grain market for forward contracts, bln. rub. 


\section{Results}

Since March 2017, Moscow Exchange has been actively working with two financial instruments - a delivery forward contract, involving the settlement of transactions from 3 to 180 days, and a delivery swap contract.

Forward contracts are a relatively new tool in the agricultural market and provide for delivery in a certain period of time with a price no lower than the market price. The farmer is sure of it and does not think about the price after the harvest. Its use may be dictated by several reasons: the ability to insure the crop against bad weather, the availability of a buyer, and final settlement at market prices. They insure producers, give them certainty and allow them to have a planning horizon.

Compared with other mechanisms, for example, bank loans, forward contracts have a major advantage. Firstly, farmers receive funds for works on the security of the future harvest. Secondly, the payment is made at market prices.

The point of such an agreement is that the initially stated conditions cannot be changed by any party and are guaranteed to be executed on the stipulated date. All terms and conditions of the forward deal are fixed and included in the contract, which protects the supplier from the risk of financial losses.

The forward clearly identifies the buyer and the terms of the deal even before the crop is harvested. In most cases, the contract is concluded before the planting season, which simplifies the seller's financial situation and allows him to use the maximum amount of resources available to complete the deal and make his own profit.

The defining features of a forward contract and its differences from other types of similar agreements are presented in Table 2.

Table 2. Features of a forward contract and its differences from other types of similar agreements

\begin{tabular}{|c|l|l|}
\hline No. & \multicolumn{1}{|c|}{ Signs of a forward contract } & \multicolumn{1}{c|}{ Differences from other types of similar agreements } \\
\hline 1 & $\begin{array}{l}\text { Place of conclusion of the } \\
\text { agreement }\end{array}$ & $\begin{array}{l}\text { Forward contract is concluded off-exchange, unlike a similar agreement } \\
\text { - futures }\end{array}$ \\
\hline 2 & Term of the contract & Forward contract maturity may be whatever term the parties agree on \\
\hline 3 & Deal standard & There is no strict standard for forward deals, unlike for futures \\
\hline 4 & Reporting & There is no reporting obligation under forward contracts \\
\hline 5 & Agreement & Forward contracts may not be broken or altered by either party \\
\hline 6 & Form of agreement & Have a free form with regard to expression of will \\
\hline 7 & The inviolability of the contract & Forward has no retroactive effect \\
\hline 8 & Contract costs & Parties shall not bear expenses for conclusion of a forward contract \\
\hline
\end{tabular}

Forward contracts have the following basic characteristics:

1. The subject of the contract - sold types of agricultural products - spring and winter wheat, winter rye, barley, oats, peas, outdoor vegetables, etc.

2. The quantity of agricultural products to be delivered should be specified in convenient units for the customer.

3. The date of delivery of agricultural products, firmly fixed and not subject to change.

4. Delivery price (performance) - the amount paid by the buyer of agricultural products to the seller (fixed in the terms of the contract, can not be changed).

5. Forward price - the same delivery price, not unchanging, but determined at a particular time.

6. Price of the forward agreement - the difference between the forward price and the delivery price. It may be necessary to calculate if the forward contract is an object of resale on the secondary market. In such circumstances, the forward price at the time of resale of the contract is taken as the first indicator.

The characteristic of forward contracts is presented in Table 3.

Forward price (FP) is the price of the underlying asset for a certain time in the future, for example, a fivemonth forward price, etc. The forward contract price is determined from the cash price at the time of the transaction (spot price, Sp), to which overhead costs (cost of carry) are added. Depending on the asset type, the overhead may include: interest on loans, dividends, storage and insurance fees, transportation costs, etc. Thus, in the most general terms:

Forward Price $(\mathrm{FP})=$ Cash Price $(\mathrm{Cp})+$ Overhead (1).

Table 3. Characteristics of forward contracts

\begin{tabular}{|c|l|l|}
\hline No. & \multicolumn{1}{|c|}{$\begin{array}{c}\text { At the time of } \\
\text { conclusion }\end{array}$} & \multicolumn{1}{c|}{ On a future date } \\
\hline 1 & $\begin{array}{l}\text { Reconciliation: } \\
\text { - price; } \\
\text { - quality and quantity; } \\
\text { - estimated date; } \\
\text { - place of delivery; } \\
\text { - other conditions. }\end{array}$ & $\begin{array}{l}\text { Settlement: } \\
\text { - delivery on the } \\
\text { agreed day, place, } \\
\text { on the agreed } \\
\text { terms; } \\
\text { payment on } \\
\text { delivery. }\end{array}$ \\
\hline
\end{tabular}

Forward price is calculated in such a way that it is impossible to obtain arbitrage profit, i.e., to re-buy or resell the contract asset for a profit, because the forward price was understated or overstated.

A commodity forward has the following form:

$$
F P=S p \times[1+(R F R+S i c) \times(S p / \text { Lyear })],
$$
rubles;

where FP is the forward price of the commodity,

$\mathrm{Sp}$ - spot price of goods, rubles;

Fc - forward contract period, days; 
RFR - risk-free investment rate for the period Tf, fractions of one unit;

Sic - storage and insurance costs for the period Tf from the cost of goods, paid for storage and insurance, fractions of one unit;

Lyear - the length of the fiscal year, days.
Let's calculate the forward price for the period of the forward contract of grain and leguminous crops produced in the Republic of Tatarstan. Table 4 shows the data on the volume of grain production and sales in the Republic of Tatarstan for 2015-2019.

Table 4. Gross grain harvest in the Republic of Tatarstan

\begin{tabular}{|c|c|c|c|c|c|c|}
\hline \multirow{2}{*}{ No. } & \multirow{2}{*}{ Indictors } & \multicolumn{5}{|c|}{ Grain harvested by year } \\
\hline & & 2015 & 2016 & 2017 & 2018 & 2019 \\
\hline \multirow{4}{*}{1} & $\begin{array}{l}\text { Grain production (at net } \\
\text { weight), thousand tons: }\end{array}$ & 3367,7 & 4115,1 & 4879,8 & 3657,6 & 4167,9 \\
\hline & $\begin{array}{l}\text { agricultural organizations, } \\
\text { thousand tons }\end{array}$ & 2753,9 & 3348,2 & 3851,5 & 2890,8 & 3151,6 \\
\hline & households, thousand tons & - & 9,9 & 11,6 & 7,8 & 5,4 \\
\hline & $\begin{array}{l}\text { peasant farms, individual } \\
\text { entrepreneurs, thousand } \\
\text { tons }\end{array}$ & 613,8 & 757,0 & 1016,7 & 759,0 & 1010,9 \\
\hline 2 & $\begin{array}{l}\text { Sales of grain by large and } \\
\text { medium agricultural } \\
\text { organizations, thousand tons }\end{array}$ & 1808,6 & 2071,7 & 2410,6 & 2524,5 & 2363,6 \\
\hline 3 & $\begin{array}{l}\text { Sales of grain by large and } \\
\text { medium agricultural } \\
\text { organizations, mln. rubles }\end{array}$ & 14273,5 & 16979,7 & 15288,0 & 20251,6 & 21738,0 \\
\hline 4 & $\begin{array}{l}\text { Cereals and leguminous } \\
\text { crops, rubles/ton }\end{array}$ & 7892 & 8196 & 6342 & 8022 & 9197 \\
\hline
\end{tabular}

As we can see from Table 4, the spot price of grain and leguminous crops in 2019 is 9197 rubles per ton, the Bank of Russia key rate (risk-free rate) for the period from April 1 to September 1, 2020 is 6\% per annum. Crop storage and insurance costs for this period are $10 \%$ of the spot price of grain and leguminous crops. The forward price for the period of the forward contract of grain and legume crops will be:

$\mathrm{FP}=9197 \times[1+(0.06+0.1) \times(150 / 366)]=$ 9800.08 rubles.

As of March 2020, the forward delivery price of grain and leguminous crops produced in the Republic of Tatarstan will be $9,800.08$ rubles per ton. It takes into account the market conditions for March-April 2020, and this price is the contract delivery price. Since this price takes into account all the conjuncture conditions, at this moment it is the forward price of the asset for a certain moment in the future.

However, market conditions may change at subsequent points in time. On the basis of this, a new delivery price may occur in a new contract for grains and legumes, which is based on the new forward price of the underlying asset.

For each given moment, the forward price of the underlying asset is the delivery price of the forward contract concluded at that moment.

Having the opportunity to choose the way of financing - forward (futures as one of the options) and crediting, agricultural producers are increasingly preferring the conclusion of a sales contract before the sowing season. In addition to the already indicated advantages of such transactions, this type of financing has other advantages:
- term of conclusion of a forward deal is from 3 to 10 days (in contrast - registration of a loan in the bank is less fast and takes at least a month);

- payment for the harvest is made at market prices, which enables farmers not to worry about grain prices and financial gain.

Benefits are felt by each party: farmers get confidence in the future and can afford to focus on getting the harvest, without being distracted by related tasks. Before the sowing season or after the first crops appear, the buyer enters into a contract to receive the grain in the required quantity at the time specified in the contract, which also opens up the possibility to plan.

Before entering into forward contracts, farmers have to calculate their possibilities and get a guarantee that the planned harvest will be grown and harvested in necessary volumes. Otherwise, all benefits from the deal will be lost.

Some experts who equate forward transactions with gambling and betting argue that the risk on them is very substantial, since the results cannot be fully calculated and random events have a huge impact on them. The implication of such claims is that there is currently no legal protection for forward transactions in Russia. Transactions are voluntary and, unlike settlement legal relations, where the legal obligations and rights of the parties are clearly defined, there are no such guarantees and legal protection for forward.

In this case it is necessary to use the mechanism of crop insurance under the system of marginal liability, which can be used in income insurance. If, as a result of an insured event, the level of income of the insured will be less than the set limit, the difference between the 
predetermined limit and the actually received income will be compensated [19].

When insuring crops, one should follow the Federal Law «On State Support in the Sphere of Agricultural Insurance» and on Amendments to the Federal Law «On Development of Agriculture» of 25.07.2011 No. 260-FL [20]. This Federal Law establishes that:

- the crop of grain and leguminous crops, perennial plantations, productive livestock are subject to insurance;

- the sum insured must be no less than $80 \%$ of the insured value of the insured objects. At the same time, the insurable value of a crop is determined on the basis of the average crop yield of grain and leguminous crops in a farm for the last five years and the average price of the corresponding type of products;

- the limit amounts of tariff rates for calculating the amount of budget subsidies are specified in the Agricultural Insurance Plans annually approved by the Ministry of Agriculture of the Russian Federation. At the same time the share of insurance premiums intended for insurance and compensation payments cannot be less than $80 \%$.

For these purposes a single association forms a compensation payments fund, which is filled from the transfer of insurers part of the insurance premium received under agricultural insurance contracts with state support. In addition, within the association of insurers common standards for insurance and damage estimation are established for the purpose of simplifying the procedure of insurance and payment of insurance compensation.

Order of the Ministry of Agriculture of Russia No. 589 of 02.10 .2020 approved the «Plan of agricultural insurance for 2021». Agricultural Insurance Plan for 2021 was developed in accordance with Article 6 of the Federal Law of July 25, 2011 No. 260-FL «On state support in the field of agricultural insurance» and on amendments to the Federal Law «On the development of agriculture» and includes:

1) The list of objects of agricultural insurance by types, groups of crops, perennial plantations, the insurance of which is subject to state support in 2021. Thus, the list of objects of agricultural insurance includes grain and leguminous crops.

2) Rate limits for calculation of the amount of subsidies for agricultural insurance of crops, plantations of perennial plants, calculated including the use of actuarial methods and differentiated in relation to the subjects of the Russian Federation and the objects of agricultural insurance, taking into account the climatic conditions of growing of agricultural crops, as well as participation of the insured in the risk (Table 5, Table 6)

The limiting rate for calculation of the amount of the subsidy is equal to the product of the basic limiting rate which is determined with consideration of the subject of the Russian Federation, the object of agricultural insurance and the participation of the insured in the risk, and the resulting correction factor which is determined depending on the event (events) stipulated in the agricultural insurance contract, against which the risk of loss (destruction) of the insured object is insured. The final adjustment coefficient is equal to the sum of adjustment coefficients set for the event (events, groups of events) in accordance with the table. If the obtained amount exceeds 1 , the final adjustment coefficient is set equal to 1 .

If the agricultural insurance contract reflects a condition on the application of an unconditional deductible that differs from the values indicated in the table, then the base limit rate is applied, indicated for the next higher value of the unconditional deductible.

At the same time, it should be noted that a new agricultural insurance system should be operational in the Russian Federation by the middle of 2021.

The amendments to Federal Law No. 260 will significantly expand the range of insurance programs offered:

1. Insurance of a new risk - «declaration of an emergency situation in the territory of a constituent entity of the Russian Federation».

2. The increase of insurance premium subsidizing from $50 \%$ to $80 \%$ for small and medium agricultural producers.

3. Separate requirements for insurance companies that insure against the risk of «emergency declaration».

4. Creation of a separate fund for compensation payments for the risk of «emergency declaration».

5 . Introduction of additional insurance programs.

The main goals and benefits of the proposed changes:

1. In terms of insurance of the new risk «declaration of emergency on the territory of the subject of the Russian Federation»:

- significant reduction of costs of the farmer (5-6 times compared to the multi-risk program);

- saving of budget funds (due to the replacement of payments in an emergency situation by the insurance payments);

- maximum possible simplified mechanism of settlement of losses;

- the shortest possible time to obtain the insurance payout;

- reducing the costs of the insurer to support the contract and the settlement of losses;

- in terms of implementation of additional insurance programs.

2. Possibility to develop insurance programs that meet the requirements of farmers of particular industries or regions, for example:

- insurance of agricultural producers' income;

- quality insurance;

- index insurance, etc. 
Table 5. Basic marginal rates, taking into account the participation of the insured in the risk (for the Republic of Tatarstan)

\begin{tabular}{|c|c|c|c|c|c|c|c|c|c|c|}
\hline \multirow[t]{2}{*}{ Crop groups } & \multirow[t]{2}{*}{ Types of crops } & \multicolumn{9}{|c|}{$\begin{array}{l}\text { Basic limit rates, taking into account the share of the } \\
\text { insured's participation in the risk (as a percentage of the } \\
\text { insured amount), \% }\end{array}$} \\
\hline & & 10 & 15 & 20 & 25 & 30 & 35 & 40 & 45 & 50 \\
\hline \multirow[t]{5}{*}{ Grain crops } & Winter wheat & 6,0 & 5,0 & 4,0 & 3,3 & 2,9 & 2,8 & 2,4 & 2,2 & 2,1 \\
\hline & Winter rye & 8,6 & 7,2 & 5,6 & 4,4 & 3,5 & 3,3 & 2,6 & 2,1 & 1,8 \\
\hline & Spring wheat & 6,6 & 5,5 & 4,3 & 3,4 & 2,6 & 2,4 & 1,9 & 1,6 & 1,3 \\
\hline & Spring barley & 6,2 & 5,1 & 4,0 & 3,1 & 2,4 & 2,2 & 1,8 & 1,5 & 1,3 \\
\hline & Other cereals & 5,6 & 4,6 & 3,6 & 2,7 & 2,0 & 1,9 & 1,6 & 1,3 & 1,2 \\
\hline Grain legumes & All kinds & 9,0 & 7,5 & 6,1 & 4,5 & 3,5 & 3,2 & 2,5 & 1,9 & 1,6 \\
\hline
\end{tabular}

Table 6. Correction coefficients to the basic marginal rates (for the Republic of Tatarstan)

\begin{tabular}{|c|c|c|c|c|c|c|c|c|c|c|c|}
\hline & & & $\begin{array}{l}\text { stment coe } \\
\text { ts), from tl } \\
\text { object }\end{array}$ & $\begin{array}{l}\text { ients } t \\
\text { mpact } \\
\text { nsured }\end{array}$ & $\begin{array}{l}\text { bas } \\
\text { vhicl } \\
\text { accor }\end{array}$ & & $\begin{array}{l}\text { tes de } \\
\text { the ri } \\
\text { h the }\end{array}$ & endin & $\begin{array}{l}\text { on the e } \\
\text { (destruc } \\
\text { al insur }\end{array}$ & $\begin{array}{l}\text { (events, gr } \\
\text { n) of the ins } \\
\text { ce contract }\end{array}$ & \\
\hline 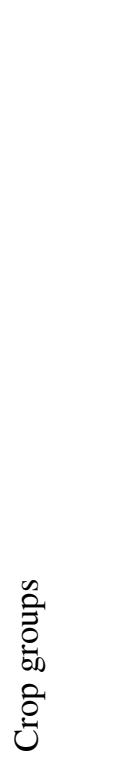 & 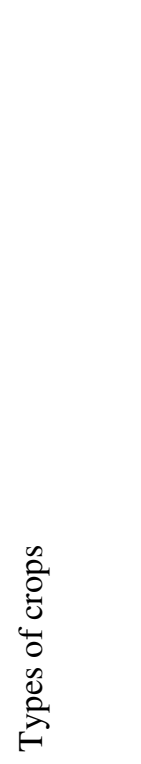 & 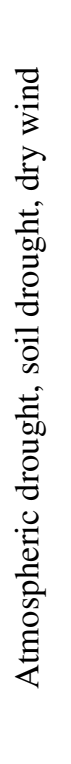 & 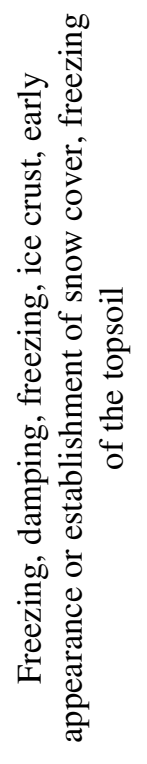 & 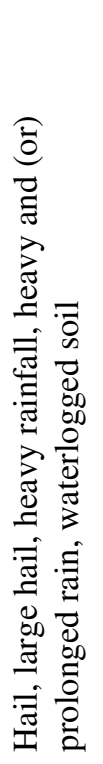 & 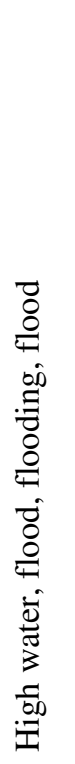 & 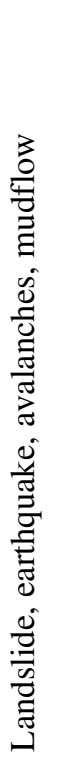 & 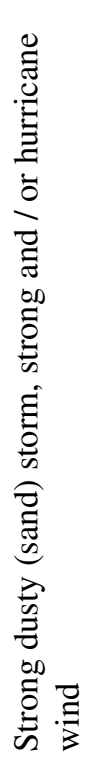 & 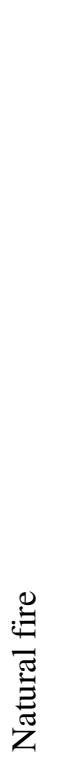 & 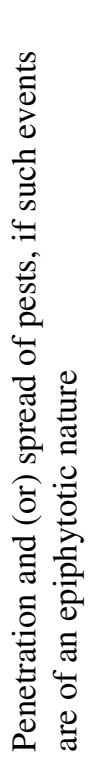 & 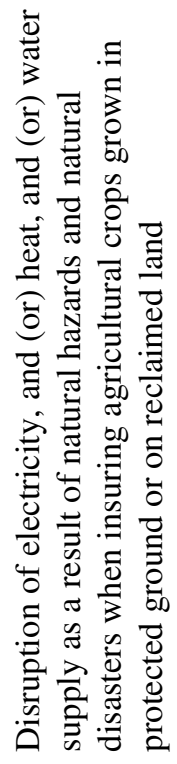 & 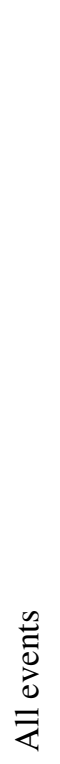 \\
\hline \multirow{5}{*}{$\begin{array}{l}\text { Cereal } \\
\text { crops }\end{array}$} & $\begin{array}{l}\text { Winter } \\
\text { wheat }\end{array}$ & 0,8 & 0,1 & 0,2 & 0,0 & 0,0 & 0,0 & 0,1 & 0,1 & 0,1 & 1 \\
\hline & $\begin{array}{l}\text { Winter } \\
\text { rye }\end{array}$ & 0,8 & 0,1 & 0,2 & 0,0 & 0,0 & 0,0 & 0,1 & 0,1 & 0,1 & 1 \\
\hline & $\begin{array}{l}\text { Spring } \\
\text { wheat }\end{array}$ & 0,8 & 0,2 & 0,2 & 0,0 & 0,0 & 0,0 & 0,1 & 0,1 & 0,1 & 1 \\
\hline & $\begin{array}{l}\text { Spring } \\
\text { barley }\end{array}$ & 0,8 & 0,2 & 0,2 & 0,0 & 0,0 & 0,0 & 0,1 & 0,1 & 0,1 & 1 \\
\hline & $\begin{array}{l}\text { Other } \\
\text { grains }\end{array}$ & 0,8 & 0,2 & 0,2 & 0,0 & 0,0 & 0,0 & 0,1 & 0,1 & 0,1 & 1 \\
\hline $\begin{array}{l}\text { Grain } \\
\text { legumes }\end{array}$ & All kinds & 0,6 & 0,6 & 0,0 & 0,0 & 0,0 & 0,0 & 0,1 & 0,1 & 0,1 & 1 \\
\hline
\end{tabular}

\section{Conclusion}

The economic efficiency of the agricultural sector of the economy is largely determined by the organization of the sales process, the choice of marketing channels. Most agricultural producers offer goods to consumers through intermediaries, reducing the commercial costs associated with the sale of agricultural products.
Agricultural producers can use both wholesale and retail trade. Retail trade makes it possible to bring products to the final consumer, but commercial costs increase significantly. Wholesale trade can be organized through federal and regional food funds, grain processing organizations, commodity exchanges, auctions and fairs, which makes it possible to promptly sell products in the places of their production. 
From the economic point of view a commodity exchange is a wholesale market, where goods are sold in accordance with models and standards on the basis of future supply contracts. The result of an exchange transaction is the conclusion of a transaction between the seller and the buyer on the mutual transfer of rights and obligations for grain and leguminous crops traded on the exchange. They are reflected in exchange contracts concluded by participants in the course of exchange transactions.

In the current economic situation, successful sales of agricultural products can pass through the exchange market through forward (futures) contracts on the immediate transfer of rights and obligations to perform real delivery of agricultural products in the future on a certain date.

\section{References}

1. A.K. Subaeva, N.M. Yakushkin, M.M. Nizamutdinov, L.M. Mavlieva, Development of cooperation in the framework of strengthening the material and technical base of small forms of Economy, Revista Publicando, 4(12(1)), 568-577 (2017)

2. G. Klychova, A., Zakirova, K. Pinina, Y. Ryazanova, R. Mannapova, Assessment of the efficiency of investing activities of organizations, E3S Web of Conferences, 110, 02075 (2019)

3. F. Mukhametgaliev, L. Sitdikova, F. Avkhadiev, I. Gainutdinov, V. Petrova, Problems of regional grain market development, BIO Web of Conferences, 17, 00082 (2020)

4. V. Borisova, I. Samoshkina, Investment Management of Agro-Ecological Farms, BIO Web of Conferences, 10, 01003 (2018)

5. A. Klychova, G. Klychova, A. Zakirova, E. Philippova, R. Sungatullina, K. Mukhamedzyanov, Social development mechanism of an agricultural enterprise formation, E3S Web of Conferences, 110, 02072 (2019)

6. F. Avkhadiev, N. Asadullin, I. Gainutdinov, L. Mikhailova, Justification of promising areas of development of agricultural organizations, BIO Web of Conferences, 27, 00100 (2020)

7. S. A. Hairston, M. R. Brooks, Derivative accounting and financial reporting quality: A review of the literature, Advances in Accounting, 44, 81-94 (2019)

8. A. R. Abdel-khalik, Po-Ch. Chen, Growth in financial derivatives: The public policy and accounting incentives, Journal of Accounting and Public Policy, 34, 291-318 (2015)

9. P. Bachiller, S. Boubaker, S. Mefteh-Wali, Financial derivatives and firm value: What have we learned? Finance Research Letters, 39, 101573 (2021).

10. R. P. Pradhan, J. H. Hall, E. du Toit, The lead-lag relationship between spot and futures prices: Empirical evidence from the Indian commodity market, Resources Policy, 70, 101934 (2021)

11. S. Basu, Spot and futures markets - Scope for integration, IIMB Management Review, 32, 336-345 (2020)

12. G. Alexandridis, Zh. Chen, Y. Zeng, Financial hedging and corporate investment, Journal of Corporate Finance, 67, 101887 (2021)

13. R. Adhikari, K. J. Putnam, Comovement in the commodity futures markets: An analysis of the energy, grains, and livestock sectors, Journal of Commodity Markets, 18, 100090 (2020).

14. N. Sobti, Determinants of a successful commodity contract: Evidence from the Indian agriculture futures market, IIMB Management Review, 32, 376388 (2020)

15. A. Hadian, C. Adaoglu, The effects of financial and operational hedging on company value: The case of Malaysian multinationals, Journal of Asian Economics, 70, 101232 (2020)

16. R. V. Chikulaev, Use of financial instruments to increase the capitalization of agro-industrial complexes, BIO Web of Conferences, 17, 00223 (2020)

17. L. Elliott, M. Elliott, Ch Te Slaa, Zh.Wang, New generation grain contracts in corn and soybean commodity markets, Journal of Commodity Markets, 20, 100113 (2020)

18. N. Sobti, Determinants of a successful commodity contract: Evidence from the Indian agriculture futures market, IIMB Management Review, 32, 376388 (2020)

19. A. Nosov, O. Tagirova, M. Fedotova, Agrarian insurance in Russia: condition, difficulties, and ways of their overcoming, BIO Web of Conferences, 17, 00136 (2020)

20. Federal Law No. 260-FL of 25.07.2011 «On state support in the sphere of agricultural insurance» and on making amendments to the Federal Law «On development of agriculture» (revised on 01.05.2019) 